\title{
Oxygen Production by Urban Trees in the United States
}

\author{
David J. Nowak, Robert Hoehn, and Daniel E. Crane
}

\begin{abstract}
Urban forests in the coterminous United States are estimated to produce $\approx 61$ million metric tons (67 million tons) of oxygen annually, enough oxygen to offset the annual oxygen consumption of approximately two-thirds of the U.S. population. Although oxygen production is often cited as a significant benefit of trees, this benefit is relatively insignificant and of negligible value as a result of the large oxygen content of the atmosphere. Other benefits of the urban forest are more critical to environmental quality and human health than oxygen production by urban trees.
\end{abstract}

Key Words. Air quality; environmental quality; tree benefits; urban forests.

Urban vegetation, particularly trees, provides numerous benefits that can improve environmental quality and human health in and around urban areas. These benefits include improvements in air and water quality, building energy conservation, cooler air temperatures, reductions in ultraviolet radiation, and many other environmental and social benefits (Nowak and Dwyer 2007). Although many ecology textbooks reveal that the vast majority of oxygen-producing organisms in the world are aquatic, oxygen production is one of the most commonly cited benefits of urban trees. Common questions related to the benefits of urban forests are directed toward understanding the amount of oxygen produced by urban forests, often in relation to the amount of oxygen consumed by humans. It is well known that trees produce oxygen, but how significant is the oxygen production benefit provided by urban forests?

The purpose of this article is to estimate the oxygen production by urban forests in select cities and nationally, compare it with estimated oxygen consumption by the U.S. population, illustrate why oxygen production by urban trees is a relatively unimportant benefit, and compare this benefit with other environmental benefits provided by urban trees and forests.

\section{METHODS}

\section{Field Data}

Randomly located 0.04 ha $(0.1 \mathrm{ac})$ field plots were measured in 16 cities to sample the entire urban forest structure of that city (e.g., tree species composition, number of trees on all land uses) (Table 1). These cities were sampled in collaboration with a number of cooperators, all of whom used methods developed by the USDA Forest Service for various urban forest research projects (e.g., Nowak and Crane 2000; Nowak et al. 2005). Data collection included land use, tree species, stem diameter at $1.37 \mathrm{~m}(4.5 \mathrm{ft})$ above the ground $(\mathrm{dbh})$, tree and crown heights, crown width, and canopy condition.

\section{Oxygen Production by Trees}

Net oxygen production by trees is based on the amount of oxygen produced during photosynthesis minus the amount of oxygen consumed during plant respiration (Salisbury and Ross 1978):

Photosynthesis: $n\left(\mathrm{CO}_{2}\right)+n\left(\mathrm{H}_{2} \mathrm{O}\right)+$ light $\rightarrow\left(\mathrm{CH}_{2} \mathrm{O}\right)_{n}+n \mathrm{O}_{2}$ Respiration: $\left(\mathrm{CH}_{2} \mathrm{O}\right)_{n}+n \mathrm{O}_{2} \rightarrow n\left(\mathrm{CO}_{2}\right)+n\left(\mathrm{H}_{2} \mathrm{O}\right)+$ energy

If carbon dioxide uptake during photosynthesis exceeds carbon dioxide release by respiration during the year, the tree will accumulate carbon (carbon sequestration). Thus, a tree that has a net accumulation of carbon during a year (tree growth) also has a net production of oxygen. The amount of oxygen produced is estimated from carbon sequestration based on atomic weights:

$$
\text { net } \mathrm{O}_{2} \text { release }(\mathrm{kg} / \mathrm{yr})=\text { net } \mathrm{C} \text { sequestration }(\mathrm{kg} / \mathrm{yr}) \times 32 / 12
$$

\section{Tree Biomass}

The net amount of oxygen produced by a tree during a year is directly related to the amount of carbon sequestered by the tree, which is tied to the accumulation of tree biomass. Biomass for each measured tree was calculated using equations from the literature with inputs of dbh and tree height (see Nowak 1994; Nowak et al. 2002a). Equations that predict aboveground biomass were converted to whole tree biomass based on a belowground to aboveground ratio of 0.26 (Cairns et al. 1997). Equations that compute fresh weight biomass were multiplied by species- or genus-specific conversion fac- 
Table 1. Summary of data collection in cities using 0.04 ha circular plots.

\begin{tabular}{lll}
\hline City & Year & Number of plots \\
\hline Atlanta, GA & 1997 & 205 \\
Baltimore, MD & 1999 & 200 \\
Boston, MA & 1996 & 217 \\
Calgary, Alberta & 1998 & 350 \\
Freehold, NJ & 1998 & 144 \\
Jersey City, NJ & 1998 & 220 \\
Minneapolis, MN & 2004 & 110 \\
Moorestown, NJ & 2000 & 206 \\
Morgantown, WV & 2004 & 136 \\
New York, NY & 1996 & 206 \\
Philadelphia, PA & 1996 & 210 \\
San Francisco, CA & 2004 & 194 \\
Syracuse, NY & 2001 & 197 \\
Toronto, Ontario & & 211 \\
Washington. DC $^{\mathrm{x}}$ & 2000 & 201 \\
Woodbridge, NJ $^{\mathrm{z}}$ & 2004 & 215 \\
\hline
\end{tabular}

${ }^{\mathrm{z}}$ Nowak et al. $2006 \mathrm{~b}$.

y Nowak and O'Connor 2001.

${ }^{\mathrm{x}}$ Kenney et al. 2001.

${ }^{w}$ Nowak et al. 2006c.

tors to yield dry weight biomass. These conversion factors, derived from average moisture contents of species given in the literature, averaged 0.48 for conifers and 0.56 for hardwoods (Nowak 1994).

Open-grown, maintained trees tend to have less aboveground biomass than predicted by forest-derived biomass equations for trees of the same diameter at breast height (Nowak 1994). To adjust for this difference, biomass results for open-grown urban trees were multiplied by a factor of 0.8 (Nowak 1994). No adjustment was made for trees found in more natural stand conditions (e.g., vacant lands, forest preserves). Because deciduous trees drop their leaves annually, only carbon stored in woody biomass was calculated for these trees. Total tree dry weight biomass (above- and belowground) was converted to total stored carbon by multiplying by 0.5 .

Multiple equations developed for a single tree species were combined to produce one predictive equation for a wide range of diameters for each species. The process of combining the individual formulas (each with limited diameter ranges) into one more general species formula produced results that were typically within $2 \%$ of the original estimates for total carbon storage of the urban forest (i.e., the estimates using the multiple equations). Formulas were combined to prevent disjointed sequestration estimates that can occur when calculations switch between individual biomass equations.

If no biomass equation could be found for an individual species, the average of results from equations of the same genus was used. If no equations for the genus were found, the average of results from all broadleaf or conifer equations was used.

Standard errors given for carbon report sampling error rather than error of estimation. Estimation error is unknown and likely larger than the reported sampling error. Estimation error also includes the uncertainty of using biomass equations and conversion factors, which may be large, as well as measurement error, which is typically small.

\section{Urban Tree Growth and Carbon Sequestration}

Average diameter growth from the appropriate land use and diameter class was added to the existing tree diameter (year $x$ ) to estimate tree diameter in year $x+1$. For urban trees in forest stands, average dbh growth was estimated as $0.38 \mathrm{~cm} /$ year (0.15 in/year) (Smith and Shifley 1984); for trees on land uses with a park-like structure (e.g., parks, cemeteries, golf courses), average dbh growth was $0.61 \mathrm{~cm} /$ year $(0.24$ in/year $)$ (deVries 1987); for more open-grown trees, dbh classspecific growth rates were based on Nowak (1994). Average height growth was calculated based on formulas from Fleming (1988) and the specific dbh growth factor used for the tree.

Growth rates were adjusted based on tree canopy condition. Adjustment factors were proportional to percent crown dieback (i.e., the greater the crown dieback, the slower the growth rate) and the assumption that less than $25 \%$ crown dieback had a limited effect on dbh growth rates. For trees with fair to excellent condition (less than 25\% dieback), no adjustment was made to the growth rate; for poor condition trees (26\% to $50 \%$ dieback), growth rates were multiplied by 0.76 ; critical trees ( $51 \%$ to $75 \%$ dieback) by 0.42 ; dying trees ( $76 \%$ to $99 \%$ dieback) by 0.15 ; and dead trees by 0 . The difference in estimates of carbon storage between year $x$ and year $x+1$ is the net amount of carbon sequestered annually.

Tree death leads to the eventual release of stored carbon. To estimate the net amount of carbon sequestered by the urban trees after decomposition, carbon emissions resulting from decomposition after tree death must be considered. To calculate the potential release of carbon resulting from tree death and decomposition, estimates of annual mortality rates by condition class were derived from a study of street-tree mortality (Nowak 1986). Annual mortality was estimated as $1.9 \%$ for trees 0 to 3 in dbh in the good-excellent condition class (less than $10 \%$ dieback); $1.5 \%$ for trees greater than 3 in $\mathrm{dbh}$ in the good-excellent condition class; $3.3 \%$ for trees in fair condition ( $11 \%$ to $25 \%$ dieback); $8.9 \%$ for poor condition; $13.1 \%$ for critical condition; $50 \%$ for dying; and $100 \%$ for dead.

Two types of decomposition rates were used: 1) rapid release for aboveground biomass of trees that are projected to be removed and 2) delayed release for standing dead trees and tree roots of removed trees. Trees that are removed from urban sites are not normally developed into wood products that provide for long-term carbon storage (i.e., removed trees 
are often burned or mulched); therefore, they will most likely release their carbon relatively soon after removal.

If dead trees are not removed annually, they have an increased probability of being measured in the tree sample, and decomposition rates must reflect this difference. All trees on vacant, transportation, and agriculture land uses, and 50\% of trees in parks, were assumed to be left standing (i.e., not removed) because these trees are likely within forest stands and/or away from intensively maintained sites. These trees were assumed to decompose over a period of 20 years. Data on tree decomposition rates are limited. However, using decomposition rates from 10 to 50 years had little effect on overall net decomposition within a single year. Trees on all other land uses were assumed to be removed within 1 year of tree death. For removed trees, aboveground biomass was assumed to be mulched with a decomposition rate of 3 years; below-ground biomass was assumed to decompose in 20 years. Although no mulch decomposition studies could be found, studies on decomposition reveal that $37 \%$ to $56 \%$ of carbon in tree roots and $48 \%$ to $67 \%$ of carbon in twigs is released within the first 3 years (Scheu and Schauermann 1994).

Estimates of carbon emissions resulting from decomposition were based on the probability of the tree dying within the next year and the probability of the tree being removed using the formula:

$$
\begin{aligned}
\text { Emission } & =\mathrm{C} \times \mathrm{M}_{\mathrm{c}} \times \sum \mathrm{p}_{\mathrm{i}}\left(\left(\mathrm{D}_{\text {remove }}\right)+\left(\mathrm{D}_{\text {stand }}\right)\right) \\
\mathrm{D}_{\text {remove }} & =\left(\mathrm{p}_{\mathrm{ab}} / \mathrm{y}_{\mathrm{i}}\right)\left(1 / \mathrm{d}_{\mathrm{m}}\right)+\left(\left(1-\mathrm{p}_{\mathrm{ab}}\right) / \mathrm{y}_{\mathrm{i}}\right)\left(1 / \mathrm{d}_{\mathrm{r}}\right) \\
\mathrm{D}_{\text {stand }} & =\left(\left(\mathrm{y}_{\mathrm{i}}-1\right) / \mathrm{y}_{\mathrm{i}}\right)\left(1 / \mathrm{d}_{\mathrm{r}}\right)
\end{aligned}
$$

where emission $=$ individual tree contribution to carbon emissions; $\mathrm{C}=$ carbon storage in the next year; $\mathrm{M}_{\mathrm{c}}=$ probability of mortality based on condition class; $\mathrm{i}=$ decomposition class (based on number of years left standing before removal); $\mathrm{p}_{\mathrm{i}}=$ proportion of the land use tree population in decomposition class $\mathrm{i} ; \mathrm{p}_{\mathrm{ab}}=$ proportion of tree biomass aboveground; $y_{i}=$ number of years left standing before removal $\left(y_{i} \rightarrow \infty\right.$ for dead trees that will never be cut down (natural decomposition)); $\mathrm{d}_{\mathrm{m}}=$ decomposition rates for mulched aboveground biomass ( 3 years); and $d_{r}=$ decomposition rate for standing trees and tree roots (20 years).

Individual tree estimates of mortality probability and decomposition rates were aggregated upward to yield total estimates of decomposition for the tree population. The amount of carbon sequestered as a result of tree growth was reduced by the amount lost resulting from tree mortality to estimate a net carbon sequestration rate that accounts for carbon loss resulting from decomposition.

\section{Human Oxygen Consumption}

An average adult human oxygen consumption rate of 0.84 $\mathrm{kg} /$ day (1.85 lb/day) (Perry and LeVan c. 2003) was used to estimate how much human oxygen consumption would be offset by urban forest oxygen production annually. To estimate how much human oxygen consumption would be offset, oxygen production was divided by average annual oxygen consumption per person.

\section{RESULTS}

Net annual oxygen production by urban forests (after accounting for decomposition) in selected cities ranged from 1,000 metric tons (1,100 tons) in Freehold, New Jersey, U.S. to 86,000 metric tons ( 94,800 tons) in Atlanta, Georgia (Table 2). This net oxygen production offsets oxygen consumption from between $2 \%$ of the human population in Jersey City, New Jersey, and New York, New York, to greater than $100 \%$ in Moorestown, New Jersey. Mean net annual oxygen production (after accounting for decomposition) per hectare of trees (100\% tree canopy) offsets oxygen consumption of 19 people per year (eight people per acre of tree cover), but ranges from nine people per hectare of canopy cover (four people/ac cover) in Minneapolis, Minnesota, to 28 people/ha cover (12 people/ac cover) in Calgary, Alberta. The average number of trees needed to offset the annual oxygen consumption of one adult was 30 trees (net oxygen production after accounting for decomposition) but ranged from 17 trees in Freehold, New Jersey, to 81 trees in Calgary, Alberta. This difference is a reflection of different tree sizes, conditions, and growth rates among these cities.

Tree oxygen production varies by tree size. Based on data from Minneapolis, Minnesota (Nowak et al. 2006b), trees $1-3^{\prime \prime}$ dbh produced $\approx 2.9 \mathrm{~kg} \mathrm{O}_{2} /$ year $\left(6.4 \mathrm{lb} \mathrm{O}_{2} /\right.$ year $)$; trees 9-12" dbh: $22.6 \mathrm{~kg} \mathrm{O}_{2} /$ year (49.9 lb O$/ 2 /$ year); 18-21" dbh: $45.6 \mathrm{~kg} \mathrm{O} /$ year (100.5 lb O $2 /$ year); 27-30" dbh: $91.1 \mathrm{~kg}$ $\mathrm{O}_{2} /$ year (200.8 $\mathrm{lb} \mathrm{O}_{2} /$ year); and greater than $30^{\prime \prime}$ dbh: 110.3 $\mathrm{kg} \mathrm{O}_{2} /$ year (243.2 $\mathrm{lb} \mathrm{O}_{2} /$ year).

Based on the national estimate of net carbon sequestration in the coterminous United States of 22.8 million metric tonsC/year (25.1 million tonsC/year) (Nowak and Crane 2002), urban forests in the United States produce $\approx 61$ million metric tons (67 million tons) of oxygen annually, which is enough oxygen to offset human oxygen consumption for approximately two-thirds of the U.S. population.

\section{DISCUSSION}

Oxygen production by trees varies among cities based on differences in number of healthy trees, growth rates, and diameter distributions. Cities with mostly small trees would require more trees on average to offset the oxygen consumption of one person. Percent of the population's oxygen consumption offset by urban forests varies depending on population density and total oxygen production. Cities with high human population density (e.g., Jersey City and New York) tend to have the lowest proportion of their oxygen consumption offset by their urban forest. A commonly cited statement 
Table 2. Oxygen production by urban forests in various cities and its relative effect compared with the city population.

\begin{tabular}{|c|c|c|c|c|c|c|c|c|c|c|c|c|}
\hline \multirow[b]{2}{*}{ City } & \multicolumn{2}{|c|}{ Trees $(\times 1,000)$} & \multicolumn{4}{|c|}{$\begin{array}{l}\text { Oxygen prod. }{ }^{\mathrm{z}} \\
(\mathrm{t} / \text { year } \times 1,000)\end{array}$} & \multicolumn{2}{|c|}{ Oxygen offset ${ }^{y}$} & \multirow[b]{2}{*}{$\begin{array}{l}\text { Net } \\
\text { no./ha }\end{array}$} & \multicolumn{3}{|c|}{ Per person offset ${ }^{\mathrm{x}}$} \\
\hline & Total & SE & $\begin{array}{l}\text { Net } \\
\text { total }\end{array}$ & SE & $\begin{array}{l}\text { Net w/d } \\
\text { total }\end{array}$ & SE & $\begin{array}{l}\text { Net no. of people } \\
\text { (\% pop) }\end{array}$ & $\begin{array}{l}\text { Net w/d no. of } \\
\text { people (\% pop) }\end{array}$ & & $\begin{array}{l}\text { Net w/d } \\
\text { no./ha }\end{array}$ & $\begin{array}{l}\text { Net no. } \\
\text { of trees }\end{array}$ & $\begin{array}{l}\text { Net w/d } \\
\text { no. of trees }\end{array}$ \\
\hline Atlanta, GA & 9,415 & 749 & 112 & 8 & 86 & 12 & $366,400(88 \%)$ & $280,300(67 \%)$ & 29 & 22 & 26 & 34 \\
\hline Baltimore, MD & 2,627 & 570 & 39 & 5 & 25 & 4 & $127,700(20 \%)$ & $82,500(13 \%)$ & 29 & 19 & 21 & 32 \\
\hline Boston, MA & 1,183 & 109 & 25 & 2 & 19 & 2 & $82,900(14 \%)$ & $60,400(10 \%)$ & 26 & 19 & 14 & 20 \\
\hline Calgary, Alberta & 11,889 & 2,777 & 52 & 7 & 45 & 6 & $169,000(19 \%)$ & $147,700(17 \%)$ & 33 & 28 & 70 & 81 \\
\hline Freehold, NJ & 48 & 6 & 1 & 0 & 1 & 0 & $4,300(39 \%)$ & $2,800(25 \%)$ & 25 & 16 & 11 & 17 \\
\hline Jersey City, NJ & 136 & 22 & 2 & 0 & 2 & 0 & $7,000(3 \%)$ & $5,100(2 \%)$ & 16 & 11 & 19 & 27 \\
\hline Minneapolis, MN & 979 & 165 & 22 & 3 & 11 & 6 & $70,200(18 \%)$ & $36,200(9 \%)$ & 18 & 9 & 14 & 27 \\
\hline Moorestown, NJ & 583 & 53 & 9 & 1 & 7 & 1 & $29,700(160 \%)$ & $22,300(120 \%)$ & 28 & 21 & 20 & 26 \\
\hline Morgantown, WV & 658 & 79 & 7 & 1 & 5 & 1 & $22,800(85 \%)$ & $17,800(66 \%)$ & 29 & 22 & 29 & 37 \\
\hline New York, NY & 5,212 & 719 & 102 & 11 & 55 & 12 & $333,600(4 \%)$ & $180,500(2 \%)$ & 20 & 11 & 16 & 29 \\
\hline Philadelphia, PA & 2,113 & 211 & 39 & 4 & 29 & 4 & $127,200(8 \%)$ & $93,000(6 \%)$ & 24 & 17 & 17 & 23 \\
\hline San Francisco, CA & 668 & 98 & 12 & 2 & 11 & 1 & $40,200(5 \%)$ & $36,900(5 \%)$ & 28 & 26 & 17 & 18 \\
\hline Syracuse, NY & 876 & 119 & 13 & 1 & 11 & 1 & $42,800(29 \%)$ & $37,200(25 \%)$ & 29 & 25 & 20 & 24 \\
\hline Toronto, Ontario & 7,542 & 889 & 98 & 10 & 76 & 10 & $318,300(13 \%)$ & $246,500(10 \%)$ & 25 & 19 & 24 & 31 \\
\hline Washington, DC & 1,928 & 224 & 39 & 4 & 31 & 3 & $127,400(22 \%)$ & $101,400(18 \%)$ & 28 & 22 & 15 & 19 \\
\hline Woodbridge, NJ & 986 & 97 & 13 & 1 & 10 & 1 & $43,900(44 \%)$ & $32,000(32 \%)$ & 25 & 18 & 22 & 31 \\
\hline
\end{tabular}

${ }^{\mathrm{z}}$ Annual oxygen production by the urban forest (thousands of metric tons per year). Multiply by 1.102 to convert to tons.

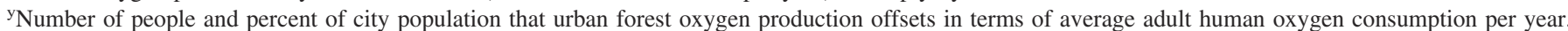

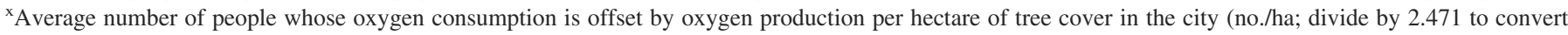
to no./ac) and average number of trees needed in city to offset the oxygen consumption of one adult human (no. of trees).

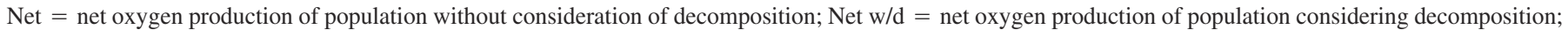
net production minus estimated oxygen consumed resulting from decomposition; $\mathrm{SE}=$ standard error.

is an acre of trees ( $100 \%$ tree canopy) can provide enough oxygen for 18 people (e.g., American Forests 2006; TreePeople 2006), but based on this study, this estimate appears to be high by at least a factor of two. The number is more on the order of eight people per acre of tree cover $(100 \%$ tree canopy). Oxygen production per acre of tree cover will vary based on tree density, diameter distribution, and tree health and growth.

Oxygen production is one of many environmental benefits that trees produce, and urban trees can produce a significant amount of oxygen. However, is this oxygen production actually creating a significant environmental benefit in comparison with other environmental benefits of trees such as carbon sequestration and air pollution removal? In the coterminous United States, annual carbon sequestration by urban forests is estimated at 22.8 million metric tons ( 25.1 million tons) with a societal value of $\approx \$ 460$ million per year (Nowak and Crane 2002). Air pollution removal in the coterminous United States is estimated at 711,000 metric tons $(784,000$ tons) with a $\$ 3.8$ billion annual value (Nowak et al. 2006a). Oxygen production by U.S. urban forests is estimated at 61 million metric tons (67 million tons), but the value to society is negligible.

The reason the oxygen production value of urban trees is insignificant has to do with the large amount of oxygen within the atmosphere (approximately $21 \%$ of the atmosphere's volume is oxygen). As stated by Miller (1979): "We have a large number of serious ecological problems, but suffocation from lack of oxygen is not one of them (Broecker 1970; SCEP 1970). The oxygen content of the atmosphere remains essentially constant with the oxygen consumed by all animals, bacteria, and respiration processes roughly balanced by the oxygen released by land and sea plants during photosynthesis. The present atmospheric oxygen content seems not to have changed since 1910 (SCEP 1970). Furthermore, because air is about 20 percent oxygen, the total supply is immense (Broecker 1970)." Our atmosphere has such an enormous reserve of oxygen that even if all fossil fuel reserves, all trees, and all organic matter in soils were burned, atmospheric oxygen would only drop a few percent (Broecker 1996). Also, waters of the world are the main oxygen generators of the biosphere; their algae are estimated to replace $\approx 90 \%$ of all oxygen used (Encyclopaedia Britannica 1994). Thus, although urban trees do produce significant amounts of oxygen, it is not a significant ecologic benefit given the global nature of oxygen and the sheer volume of oxygen in the atmosphere.

A growing forest will remove carbon dioxide and produce oxygen. Conversely, a decaying or declining forest will release carbon dioxide and consume oxygen through 
decomposition processes. If forest canopy cover is increased (more trees are added) and sustained through time, net carbon dioxide will be removed and oxygen produced. Given the carbon dioxide level in the atmosphere $(\approx 0.03 \%)$ is much less than the oxygen level $(21 \%)$, the relative impact of urban forests and their management are much more significant for carbon dioxide than for oxygen.

Fossil fuel combustion also consumes oxygen and as a result of fossil fuel use, the oxygen content of the atmosphere is slowly declining. Between 1989 and 1994, the oxygen content of the atmosphere dropped at an annual rate of $2 \mathrm{ppm}$ out of 210,000 ppm (Broecker 1996). Thus, reducing fossil fuel use in the management of urban forests not only reduces emission of carbon dioxide, but also the consumption of oxygen. If fossil fuels are consistently used to maintain an urban forest, the net effect of the forest and its management will be carbon dioxide production and oxygen consumption. The point in the future when carbon emissions from maintenance exceed carbon sequestration by the forest varies by tree species and intensity of fossil fuel-based management (Nowak et al. 2002b).

Urban trees can improve air quality (e.g., Cardelino and Chameides 1990; Taha 1996; Nowak et al. 2000, 2006a). Because small changes in air pollution concentrations can have relatively considerable impacts on air quality and human health, the effects of urban forests on air pollution can be significant. Recently, the U.S. Environmental Protection Agency has introduced urban tree cover as a potential emerging measure to help meet air quality standards (U.S. Environmental Protection Agency 2004; Nowak 2005). In general, tree effects on trace chemicals in the atmosphere (chemicals that are minor components of the total atmosphere) will have a much greater relative impact on environmental quality and human health than chemicals such as oxygen that comprise a large proportion of the atmosphere. Relatively minor changes in trace chemicals can have significant effects on environmental and human health (e.g., impacts of ozone, particulate matter, nitrogen, and sulfur oxides) and climate change (e.g., impact of carbon dioxide).

Although the absolute magnitude of oxygen production by urban forests is over 2.5 times greater than for carbon sequestration and 85 times greater than for air pollution removal nationally, the relative impacts of carbon sequestration and air pollution removal are much more significant than oxygen production. Urban forest effects on trace chemicals can lead to significant improvements in environmental quality and human health and well-being.

\section{CONCLUSION}

Urban forests produce large amounts of oxygen. However, with the large and relatively stable amount of oxygen in the atmosphere and extensive production by aquatic systems, this tree benefit is relatively insignificant. Tree impacts on important atmospheric trace chemicals such as carbon dioxide and U.S. Environmental Protection Agency criteria air pollutants (ozone, particulate matter, sulfur dioxide, nitrogen dioxide, carbon monoxide, and lead) will have greater significant impacts on human health and environmental quality. Urban forest carbon sequestration and air pollution removal along with other environmental impacts of urban forests (e.g., water quality improvement, lower air temperatures, reduced ultraviolet radiation loads) need to be better incorporated within local and regional planning efforts to improve environmental quality and enhance the quality of urban life.

Acknowledgments. This work was funded, in part, by the USDA Forest Service, RPA Assessment Staff, and State and Private Forestry, Cooperative Forestry's Urban and Community Forestry Program. Data collection in Baltimore, funded by the USDA Forest Service, is part of the National Science Foundation's Long-Term Ecosystem Research project. Data from cities in New Jersey were collected and analyzed in cooperation with Mike D'Errico and the State of New Jersey, Department of Environmental Protection and Energy, Division of Parks and Forestry; Calgary data collection was by Simon Wilkins, City of Calgary; Minneapolis data collection was by Davey Resource Group; San Francisco data collection was by Alexis Harte and the City of San Francisco; Toronto data collection was by Andy Kenney and the University of Toronto; Washington, DC, data collection was by Casey Trees Endowment Fund and the National Park Service; Morgantown data collection was by Jonathan Cumming and Sandhya Mohan (University of West Virginia); and Atlanta, Georgia, Boston, Massachusetts, New York, New York, and Philadelphia, Pennsylvania, data were collected by ACRT, Inc.

\section{LITERATURE CITED}

American Forests. 2006. American Forests Kicks Off the Holiday Season With Tips on How to Care for Your Christmas Trees. http://www.americanforests.org/news/ display.php?id = 125 (accessed 6/06).

Broecker, W.S. 1970. Man's oxygen reserve. Science 168: 1537-1538.

1996. Et tu, $\mathrm{O}_{2}$ ? 21stC, The World of Research at Columbia University. Special Issue: Biospheres. http:// www.columbia.edu/cu/21stC/issue-2.1/broecker.htm (accessed 6/06).

Cairns, M.A., S. Brown, E.H. Helmer, and G.A. Baumgardner. 1997. Root biomass allocation in the world's upland forests. Oecologia 111:1-11.

Cardelino, C.A., and W.L. Chameides. 1990. Natural hydrocarbons, urbanization, and urban ozone. Journal of Geophysical Research 95:13971-13979.

deVries, R.E. 1987. A preliminary investigation of the growth and longevity of trees in Central Park. New Brunswick, NJ, Rutgers University, MS thesis. 
Encyclopaedia Britannica. 1994. Oxygen, p. 35. Volume 9. The New Encyclopaedia Britannica, 15th Edition. Encyclopedia Britannica, Chicago.

Fleming, L.E. 1988. Growth estimation of street trees in central New Jersey. New Brunswick, NJ, Rutgers University. MS thesis.

Kenney, W.A., and Associates. 2001. The Role of Urban Forests in Greenhouse Gas Reduction. W.A. Kenney and Associates, ON ENV (99) 4691, Toronto, Canada. 202 pp.

Miller, G.T. 1979. Living in the Environment. Wadsworth Publ. Co., Belmont, CA. p. 91.

Nowak, D.J. 1986. Silvics of an urban tree species: Norway maple (Acer platanoides L.). Syracuse, NY, State University of New York, College of Environmental Science and Forestry, MS thesis.

- 1994. Atmospheric carbon dioxide reduction by Chicago's urban forest, pp. 83-94. In Chicago's Urban Forest Ecosystem: Results of the Chicago Urban Forest Climate Project. McPherson, E.G., Nowak, D.J., and Rowntree, R.A., Eds. USDA Forest Service General Technical Report NE-186, Radnor, PA.

- 2005. Strategic tree planting as an EPA encouraged pollutant reduction strategy: How urban trees can obtain credit in State Implementation Plans. Sylvan Communities. Summer/Fall:23-27.

Nowak, D.J., K.L. Civerolo, S.T. Rao, G. Sistla, C.J. Luley, and D.E. Crane. 2000. A modeling study of the impact of urban trees on ozone. Atmospheric Environment 34: $1610-1613$.

Nowak, D.J., and D.E. Crane. 2000. The urban forest effects (UFORE) model: Quantifying urban forest structure and functions, pp. 714-720. In Proceedings: Integrated Tools for Natural Resources Inventories in the 21st Century. Hansen, M., and Burk, T., Eds. IUFRO Conference, 16-20 August 1998, Boise, ID. General Technical Report NC-212, U.S. Department of Agriculture, Forest Service, North Central Research Station, St. Paul, MN.

- 2002. Carbon storage and sequestration by urban trees in the USA. Environmental Pollution 116:381-389.

Nowak, D.J., D.E. Crane, and J.C. Stevens. 2006a. Air pollution removal by urban trees and shrubs in the United States. Urban Forestry and Urban Greening 4:115-123.

Nowak, D.J., D.E. Crane, J.C. Stevens, and R. Hoehn. 2005. The Urban Forest Effects (UFORE) Model: Field Data Collection Procedures. USDA Forest Service, Syracuse, NY. http://www.fs.fed.us/ne/syracuse/Tools/downloads/ UFORE_Manual.pdf (accessed 3/07).

Nowak, D.J., D.E. Crane, J.C. Stevens, and M. Ibarra. 2002a. Brooklyn's Urban Forest. General Technical Report NE290, U.S. Department of Agriculture, Forest Service, Northeastern Research Station, Newtown Square, PA. 107 pp.
Nowak, D.J., and J.F. Dwyer. 2007. Understanding the benefits and costs of urban forest ecosystems, pp. 25-46. In Urban and Community Forestry in the Northeast. Kuser, J., Ed. Springer Science and Business Media, New York, NY.

Nowak, D.J., R. Hoehn, D.E. Crane, J.C. Stevens, and J.T. Walton. 2006b. Assessing Urban Forest Effects and Values: Minneapolis' Urban Forest. Resource Bulletin NE166. U.S. Department of Agriculture, Forest Service, Northeastern Research Station, Newtown Square, PA. 20 pp.

- 2006c. Assessing Urban Forest Effects and Values: Washington DC's Urban Forest. Resource Bulletin NRS1. U.S. Department of Agriculture, Forest Service, Northern Research Station, Newtown Square, PA. 24 pp.

Nowak, D.J., and P. O'Connor. 2001. Syracuse Urban Forest Master Plan: Guiding the City's Forest Resource in the 21st Century. General Technical Report NE-287. U.S. Department of Agriculture, Forest Service, Northeastern Research Station, Newtown Square, PA. 50 pp.

Nowak, D.J., J.C. Stevens, S.M. Sisinni, and C.J. Luley. 2002b. Effects of urban tree management and species selection on atmospheric carbon dioxide. Journal of Arboriculture 28:113-122.

Perry, J., and M.D. LeVan. c. 2003. Air Purification in Closed Environments: Overview of Spacecraft Systems. U.S. Army Natrick Soldier Center. http://nsc.natick.army.mil/ jocotas/ColPro_Papers/Perry-LeVan.pdf (accessed 6/06).

Salisbury, F.B., and C.W. Ross. 1978. Plant Physiology. Wadsworth Publishing Company, Belmont, CA. 422 pp.

Scheu, S., and J. Schauermann. 1994. Decomposition of roots and twigs: Effects of wood type (beech and ash), diameter, site of exposure and macro fauna exclusion. Plant and Soil 163:13-24.

Smith, W.B., and S.R. Shifley. 1984. Diameter Growth, Survival, and Volume Estimates for Trees in Indiana and Illinois. Res. Pap. NC-257. U.S. Department of Agriculture, Forest Service, North Central Forest Experiment Station, St. Paul, MN.

Study of Critical Environmental Problems (SCEP). 1970. Man's Impact on the Global Environment. MIT Press, Cambridge, MA.

Taha, H. 1996. Modeling impacts of increased urban vegetation on ozone air quality in the South Coast Air Basin. Atmospheric Environment 30:3423-3430.

TreePeople. 2006. Get Involved-Why Trees? http:// www.treepeople.org/vfp.dll?OakTree $\sim$ getPage $\sim$ PNPK $=$ 59 (accessed 6/06).

U.S. Environmental Protection Agency. 2004. Incorporating Emerging and Voluntary Measures in a State Implementation Plan (SIP). U.S. Environmental Protection Agency, Research Triangle Park, NC. http://www.epa.gov/ttn/ oarpg/t1/memoranda/evm_ievm_g.pdf (accessed 6/06). 
David J. Nowak (corresponding author)

Project Leader

USDA Forest Service

Northern Research Station 5 Moon Library

SUNY-ESF

Syracuse, NY 13210, U.S.

dnowak@fs.fed.us

Robert Hoehn

Biological Science Technician

USDA Forest Service

Northern Research Station 5 Moon Library

SUNY-ESF

Syracuse, NY 13210, U.S.

rhoehn@fs.fed.us

Daniel E. Crane

Information Technology Specialist

USDA Forest Service

Northern Research Station 5 Moon Library

SUNY-ESF

Syracuse, NY 13210, U.S.

dcrane@fs.fed.us

Résumé. Les forêts urbaines à l'intérieur des États-Unis produisent, selon les estimations faites, environ 61 millions de tonnes d'oxygène annuellement, soit suffisamment d'oxygène pour la consommation annuelle moyenne du $2 / 3$ de la population américaine. Même si la production en oxygène est souvent citée comme un bénéfice significatif des arbres, ce bénéfice est relativement insignifiant et est d'une valeur négligeable en raison du vaste contenu en oxygène de l'atmosphère. D'autres bénéfices de la forêt urbaine sont plus critiques pour la qualité de l'environnement et la santé humaine que la production en oxygène des arbres urbains.

Zusammenfassung. Urbane Wälder und den USA produzieren schätzungsweise 61 Millionen Tonnen Sauerstoff jährlich, genug Sauerstoff, um den jährlichen Verbrauch an Sauerstoff von 2/3 der amerikanischen Bevölkerung zu decken. Obwohl die Sauerstoffproduktion von Bäumen oft als Vorteil zitiert wird, ist dieser Vorteil relativ unsignifikant und von untergeordnetem Wert, gemessen am dem hohen Sauerstoffgehalt der Atmosphäre. Andere Vorteile der urbanen Wälder sind relevanter für die Qualität der Umwelt und der menschlichen Gesundheit als die Sauerstoffproduktion durch Bäume.

Resumen. Se estima que los bosques urbanos en los Estados Unidos producen 61 millones de toneladas métricas de oxígeno anualmente, suficiente oxígeno para compensar el consumo anual de cerca de 2/3 partes de la población de los U.S. Si bien la producción de oxígeno es con frecuencia citada como un beneficio significativo de los árboles, esta bondad es relativamente insignificante y de poco valor debido a la gran cantidad de oxígeno en la atmósfera. Otros beneficios del bosque urbano son más críticos para la calidad ambiental y la salud humana que la producción de oxígeno por los árboles urbanos. 